\title{
Estimation of Crop Loss Due to Lepidopteran Pests of Castor (Ricinus communis L.)
}

\author{
T. R. Ranganath ${ }^{1}$, B. K. Shivanna ${ }^{2}$, Lakshmana ${ }^{3}$, Jayalaxmi Narayana Hegde ${ }^{4}$, \\ K. C. Shashidara ${ }^{5}$ and A. Y. Hugar ${ }^{6}$
}

${ }^{1,4}$ Department of Agril. Entomology, College of Agriculture, Navile, UAHS Shivamogga, India

${ }^{2}$ Agricultural and Horticultural Research Station, Ullal, Mangalore, India

${ }^{4}$ Department of Agril. Engineering, College of Agriculture, Navile, Shivamogga, India

${ }^{6}$ Department of Agronomy, College of Agriculture, Navile, Shivamogga, India

*Corresponding author

\section{A B S T R A C T}

\begin{tabular}{|l|}
\hline Ke y w o r d s \\
$\begin{array}{l}\text { Castor, yield loss, } \\
\text { chlorantraniprole } \\
\text { and nylon net }\end{array}$ \\
\hline Article Info \\
\hline $\begin{array}{l}\text { Accepted: } \\
18 \text { May } 2020 \\
\text { Available Online: } \\
\text { 10 June } 2020\end{array}$ \\
\hline
\end{tabular}

Field experiments were carried out to evaluate the yield losses caused by lepidopteran pests on castor during kharif-2018-19. Semilooper, tobacco caterpillar, capsule borer were recorded as major pests. The results revealed that the treatment covered with nylon net recorded zero larval population and zero per cent capsule damage followed by the treatment protected up to 120 days (0.88 larvae / plant and $8.80 \%)$, protected up to 90 days (1.48 larvae / plant and $14.33 \%)$, protected up to 60 days (2.21 larvae / plant and $19.77 \%$ ) and protected up to 30 days (3.60 larvae / plant and $29.86 \%$ ). In the Untreated check recorded highest mean larval population of 5.21 larvae / plant and 30.15 per cent capsule damage was recorded.

\section{Introduction}

Castor (Ricinus communis L.) is an ancient and important non -edible oil seed crop containing 48 - 55 per cent oil. It has immense industrial and medicinal values. India occupies the prime position with an area of more than 11.50 lakh hectares and production of 9.20 lakh tonnes with an average yield of $1987 \mathrm{~kg} / \mathrm{ha}$. Gujarat is the largest producer of castor seed in the country and contributes 75 per cent in total domestic output (Anon, 2015). The crop is attacked by a number of insect pests which impose a great limitation in realizing the potential productivity.

Semilooper and tobacco caterpillar are active during the vegetative stage and over $50 \%$ defoliation is common in certain favourable years. Infestation of Conogethes punctiferalis starts from flowering stage onwards and the 
yield loss due to the pest is to the tune of $50 \%$ in recent years (Anon., 2006; Rao et al., 2012).

To avoid yield losses caused by these destructive insect pests and encourage cultivation of castor crop on large area and to increase the production and productivity, all efforts are needed to tackle these major insect pests by knowing its weakest links on the basis of damage caused by pests at different stages.

Information on crop losses is prerequisite provide a sound base for an integrated management schedule. However, information on the yield loss due to lepidopteron pests in castor is scanty. Hence, the present study was undertaken with the main objective of generating data on the yield losses caused by lepidopteran pests in castor.

\section{Materials and Methods}

An experiment was laid out in Randomized Block Design with four replications and six treatments with a castor hybrid DCH-177 in a plot size of $5.4 \mathrm{~m} \times 4.2 \mathrm{~m}$ during kharif-2018 in order to assess the loss in yield due to major lepidopteran pests by protecting the crop at different stages of crop growth. All the recommended packages of practices were followed for raising the crop except plant protection measures at AHRS, Bhavikere.

The following treatments were imposed during the study.

T1 - Untreated check

T2 - Cover with nylon net

T3 - Protect the crop up to 30 days

T4 - Protect the crop up to 60 days

T5 - Protect the crop up to 90 days

T6- Protect the crop up to 120 days

All the above treatments were imposed from the germination till the harvest of the crop. In the second treatment $\left(\mathrm{T}_{2}\right)$, the plots were covered with nylon net 15 days after sowing till the end. In third, fourth, fifth and sixth treatment, Chlorantraniprole 18.5 SC @ 0.3 $\mathrm{ml}$ per litre was sprayed at different growth stages to protect the crop. But in the untreated check $\left(T_{1}\right)$, crop was allowed for natural infestation by all the major lepidopteran pests. The larval counts of all major lepidopteran pests were taken in each treatment at 10 days intervals till the crop is harvested on 10 randomly selected and tagged plants and mean larval population per plant was worked out. In case of capsule borer per cent capsule damage was recorded at harvest.

At harvest, seed yield in all treatments was recorded as $\mathrm{kg} / \mathrm{plot}$ and later converted to $\mathrm{q} /$ ha.The data collected on mean larval population, per cent capsule damage and yield was subjected to appropriate statistical analysis by using analysis of variance (ANOVA), Web Agri. Stat Package (WASP2) and per cent loss in yield by major lepidopteranpests were worked out by using the formula.

Per centyield loss $=\frac{\text { Yield in caged treatment }- \text { yield in other treatments }}{\text { Yield in caged treatment }} \times 100$

\section{Results and Discussion}

Data on the incidence of major insect pests and yield losses is presented in Table1, indicated that overall mean larval population taken at ten days interval from August $1^{\text {st }}$ 2018 to January $18^{\text {th }} 2019$ in treatment covered with nylon net recorded zero larval population and zero per cent capsule damage followed by the treatment protected up to 120 days (0.88 larvae / plant and $8.80 \%)$, protected up to 90 days (1.48 larvae / plant and $14.33 \%)$, protected up to 60 days (2.21 larvae / plant and $19.77 \%$ ) and protected up to 30 days (3.60 larvae / plant and $29.86 \%$ ). In the Untreated check recorded highest mean 
larval population of $5.21 \quad$ larvae / plant and 30.15 per cent capsule damage was recorded. In the table1, crop protected through chemical at different crop phenological stages viz., 30, 60, 90 and 120 days and covered with nylon net yielded more compared to the crop left untreated.

Among these treatments, treatment covered with nylon net recorded the yield of $14.33 \mathrm{q} /$ ha with zero larval population and zero per cent capsule damage. The next best treatment was protecting the crop up to 120 days which recorded the yield of $13.45 \mathrm{q} /$ ha with a mean larval population 0.88 larvae per plant and 8.80 per cent capsule damage. It was followed by the treatment protect the crop up to 90 days which recorded the yield of $11.90 \mathrm{q} / \mathrm{ha}$ with a mean population of 1.48 larvae per plant and 14.33 per cent capsule damage.

Table.1 Estimation of crop loss in castor due to lepidopteran pests during kharif-2018

\begin{tabular}{|c|c|c|c|c|c|c|}
\hline $\begin{array}{l}\text { Sl. } \\
\text { No. }\end{array}$ & Treatments & $\begin{array}{l}\text { *Average } \\
\text { number of } \\
\text { larvae/plant }\end{array}$ & $\begin{array}{l}* * \text { Per cent } \\
\text { capsule } \\
\text { damage }(\%)\end{array}$ & $\begin{array}{l}\text { Yield } \\
\text { (kg/plot) }\end{array}$ & $\begin{array}{l}\text { Yield } \\
\text { (q/ha) }\end{array}$ & $\begin{array}{l}\text { Per cent yield } \\
\text { loss over } \\
\text { caged } \\
\text { treatment } \\
(\%)\end{array}$ \\
\hline 1 & Untreated check & $\begin{array}{c}5.21 \\
(2.37)^{\mathrm{a}}\end{array}$ & $\begin{array}{c}30.15 \\
(33.31)^{\mathrm{a}}\end{array}$ & $1.52^{\mathrm{d}}$ & $6.72^{\mathrm{d}}$ & 53.10 \\
\hline 2 & $\begin{array}{l}\text { Cover with } \\
\text { Nylon net }\end{array}$ & $\begin{array}{c}0.00 \\
(0.701)^{\mathrm{e}}\end{array}$ & $\begin{array}{c}0.00 \\
(0.58)^{\mathrm{e}}\end{array}$ & $3.25^{\mathrm{a}}$ & $14.33^{\mathrm{a}}$ & 0.00 \\
\hline 3 & $\begin{array}{l}\text { Protect the crop } \\
\text { up to } 30 \text { days }\end{array}$ & $\begin{array}{c}3.60 \\
(2.01)^{\mathrm{b}}\end{array}$ & $\begin{array}{c}59.86 \\
(33.09)^{\mathrm{a}}\end{array}$ & $1.62^{\mathrm{d}}$ & $7.16^{d}$ & 50.03 \\
\hline 4 & $\begin{array}{l}\text { Protect the crop } \\
\text { up to } 60 \text { days }\end{array}$ & $\begin{array}{c}2.21 \\
(1.63)^{\mathrm{c}}\end{array}$ & $\begin{array}{c}19.77 \\
(26.37)^{b}\end{array}$ & $2.45^{\mathrm{c}}$ & $10.80^{c}$ & 24.63 \\
\hline 5 & $\begin{array}{l}\text { Protect the crop } \\
\text { up to } 90 \text { days }\end{array}$ & $\begin{array}{c}1.48 \\
(1.39)^{\mathrm{cd}}\end{array}$ & $\begin{array}{c}14.33 \\
(22.32)^{\mathrm{c}}\end{array}$ & $2.70^{b c}$ & $11.90^{\mathrm{bc}}$ & 16.95 \\
\hline \multirow[t]{4}{*}{6} & $\begin{array}{l}\text { Protect the crop } \\
\text { up to } 120 \text { days }\end{array}$ & $\begin{array}{c}0.88 \\
(1.16)^{\mathrm{d}}\end{array}$ & $\begin{array}{c}8.80 \\
(17.27)^{\mathrm{d}}\end{array}$ & $3.05^{\mathrm{ab}}$ & $13.45^{\mathrm{ab}}$ & 6.14 \\
\hline & SEm \pm & 0.104 & 0.82 & 0.154 & 0.154 & - \\
\hline & $\begin{array}{l}\mathrm{CD} \\
(\mathrm{P}=0.05)\end{array}$ & 0.313 & 2.45 & 0.462 & 0.462 & - \\
\hline & CV (\%) & 13.33 & 7.35 & 12.60 & 12.60 & - \\
\hline
\end{tabular}

*Figures in parentheses are $\sqrt{\mathrm{X}}+0.5$ transformed values

** Figures in parentheses are angular transformed values

Means in the columns followed by the same alphabet do not differ significantly by DMRT $(\mathrm{P}=0.05)$

In the treatment protect the crop up to 60 days recorded mean population of 2.21 larvae per plant and 19.77 per cent capsule damage with a yield of $10.80 \mathrm{q} / \mathrm{ha}$ followed by the treatment protect the crop up to 30 days which recorded mean larval population of 3.60 larvae per plant and 29.86 per cent capsule damage with the yield of $7.16 \mathrm{q} / \mathrm{ha}$.
The highest mean larval population of 5.21 larvae per plant and highest per cent capsule damage 30.15 per cent with the lowest yield of $6.72 \mathrm{q} / \mathrm{ha}$ in untreated check.

Yield loss of 6.14 per cent was observed in the treatment protect the crop up to 120 days over the treatment cover with nylon net 
followed by the treatment protect the crop up to 90 days ( $16.95 \%$ ), up to 60 days protection $(24.63 \%)$ and up to 30 days protection $(50.03$ $\%)$. Untreated check recorded the highest per cent of yield loss 53.01 per cent over the treatment covered with nylon net. The insect is considered as a pest only based on the extent of damage or loss it causes to the crop. Depending upon this, the plant protection measures have to be tailored for getting higher economic returns. The present work was carried out to estimate the loss caused by major lepidopteran pests viz., castor semilooper, tobacco caterpillar and capsule borer.

In the field, experiment on yield loss due to major lepidopteran pests was worked out by adopting a differential level of insecticidal (chlorantraniliprole 18.5 SC @ 0.3ml / ltr) sprays at different crop phenological stages.

Plots covered with nylon net gave effective protection against lepidopteran pests with zero pest population and recorded maximum yield in plots covered with nylon net, as the moths cannot enter and lay the eggs and damage the crop. But plots protected up to 30 days which received one insecticidal spray further allowed for natural infestation, therefore, it recorded the lowest yield of 7.16 $\mathrm{q} /$ ha with a yield loss of 53.10 per cent and it was on par with untreated check which was completely allowed for natural infestation with yield loss of 53.10 per cent. The present results are similar with the findings of Ganesha (2011), who found that the yield loss to the tune of 55.66 per cent was recorded in unprotected plots compared to treatments receiving a differential level of insecticidal sprays.

The plots protected up- to 60 and 90 days which received 2 and 3 insecticidal sprays respectively, therefore, they recorded comparatively lesser yield and considerable per cent yield loss. The plots protected up to 120 days which received 4 insecticidal sprays registered with maximum yield with lower per cent of yield reduction. Similarly, results are in close agreement with the works of Gami et al., (2004), who found that highest mustard yield (1685 $\mathrm{kg} \mathrm{ha}^{-1}$ ) was obtained from the experimental plots having full protection against pest complex of mustard in various crop growth stages $\left(\mathrm{T}_{1}\right)$ by applying monocrotophos 0.04 per cent spray at 30,45 , 60, 75 and 90 DAS. However, it was at par with treatments $\mathrm{T}_{2}, \mathrm{~T}_{3}$ and $\mathrm{T}_{4}(1620,1580$ and $1514 \mathrm{~kg} \mathrm{ha}^{-1}$, respectively as the lowest 1045 $\mathrm{kg} \mathrm{ha}^{-1}$ in control.

The present investigation revealed the a maximum yield loss of 53.10 per cent was recorded in untreated check over the treatment which was covered with nylon net followed by the treatment which was protected up to 30 days and protected up to 60 days with 50.03 per cent and 24.63 per cent loss, respectively. However, a minimum of 6.14 per cent yield loss was recorded when the crop was protected up to 120 days with chlorantraniliprole 18.5 EC @ $0.3 \mathrm{ml} / \mathrm{lit}$, the treatment which was incidentally received four sprays up to 120 days after sowing.

\section{References}

Anonymous, 2006, Research Achievements in Castor. All India Coordinated Research Project on Castor, Directorate of Oilseeds Research, Hyderabad

Anonymous. 2015.ICAR-IIOR, Annual Report 2014-15 (Castor). Indian Institute of Oilseeds Research, Hyderabad, India. Pp: 49-62.

Gami, J. M., Bapodra And Rathod, R. R., 2004, Estimation of avoidable yield losses due to pest complex in mustard. Agric. Sci. Digest, 24(4): 309-310.

Ganesha, 2011, Studies on biology of castor shoot and capsule borer, Conogethes 
punctiferalis Guenee (Lepidoptera: Pyralidae) and its management. M.Sc. Thesis, Uni. Agri. Sci., Bengaluru, Karnataka.

Rao, M.S., Rama Rao, C.A., Srinivas, K., Pratibha, G., Vidya Sekhar, S. M and
Venkatswarlu, B. 2012. Intercropping for management of insect pests of castor, Ricinus communis in the semiarid tropics of India. Journal of Insect Science. 12: 1-10.

\section{How to cite this article:}

Ranganath. T. R., B. K. Shivanna, Lakshmana, Jayalaxmi Narayana Hegde, K. C. Shashidara and Hugar. A. Y. 2020. Estimation of Crop Loss Due to Lepidopteran Pests of Castor (Ricinus communis L.). Int.J.Curr.Microbiol.App.Sci. 9(06): 2401-2405.

doi: https://doi.org/10.20546/ijcmas.2020.906.294 